HUBUNGAN TUGAS PEKERJAAN RUMAH (PR) TERHADAP HASIL BELAJAR SISWA PENDIDIKAN KEWARGANEGARAAN DI KELAS VIII SMP SWASTA ABDI DHARMA KEC. HINAI T.P. 2018/2019

\author{
Gita Astini $^{1}$, Agustinawati ${ }^{2}$ \\ STKIP BUDIDAYA BINJAI ${ }^{1}$
}

\begin{abstract}
ABSTRAK
Penelitian ini bertujuan untuk mengetahui ada tidaknya hubungan tugas pekerjaan rumah (pr) terhadap hasil belajar siswa pendidikan kewarganegaraan di kelas VIII SMP Swasta Abdi Dharma Kec. Hinai tahun pembelajaran 2018/2019. Populasi penelitian ini adalah seluruh siswa kelas VIII yang berjumlah 30 siswa dan populasi ditetapkan 30 siswa sebagai sampel. Teknik pengambilan sampel dalam penelitian ini adalah total sampling, yakni teknik pengambilan sampel dimana jumlah sampel sama dengan populasi. Alat pengumpul data yang digunakan adalah angket tugas pekerjaan rumah (pr) sebanyak 10 item dan hasil belajar PKn siswa sebanyak 10 item. Untuk mengetahui kedua variabel maka dilakukan perhitungan menggunakan rumus korelasi " $r$ " Product Moment sederhana. Untuk mengetahui besarnya hubungan variabel $\mathrm{X}$ terhadap variabel $\mathrm{Y}$ dihitung berdasarkan uji t. Dari hasil penelitian dengan menggunakan uji hipotesis yang menggunakan uji t di peroleh harga thitung >ttabel yaitu 8,292>1,70113 serta rhitung > rtabel yaitu 0,843>0,374 maka Ho di tolak dan Ha diterima. Maka dapat disimpulkan bahwa terdapat hubungan yang signifikan antara tugas pekerjaan rumah (pr) terhadap hasil belajar siswa PKn di kelas VIII SMP Swasta Abdi Dharma Kec. Hinai Tahun Pembelajaran 2018/2019.
\end{abstract}

Kata kunci: Tugas Pekerjaan Rumah (PR), terhadap Hasil Belajar Siswa PKn

PENDAHULUAN

Pendidikan merupakan suatu proses perubahan tingkah laku sebagai hasil interaksi dengan lingkungannya untuk memenuhi kebutuhannya. Menurut W.S Winkel bahwa : "proses belajar pada pelajaran menghasilkan perubahan-perubahan dalam bidang pengetahuan, keterampilan, dan sikap yang tampak dalam prestasi yang dihasilkan terhadap pertanyaan/persoalan/tugas yang diberikan oleh pengajar".

Dalam keseluruhan proses pendidikan di sekolah, kegiatan belajar merupakan kegiatan yang paling pokok dan dasar terpenting dalam belajar untukmencapai tujuan yang telah ditetapkan. Sebagaimana yang diungkapkan oleh Slameto: 
Dalam keseluruhan proses pendidikan di sekolah, kegiatan belajar merupakan kegiatan yang paling pokok. Ini berarti berhasil atau tidaknya pencapaian tujuan pendidikan banyak bergantung kepada bagaimana proses belajar yang dialami oleh siswa sebagai anak didik.

Dalam upaya meningkatkan keberhasilan belajar siswa, seorang guru haruslah melakukan bermacam-macam usaha. Salah satu usaha tersebut yakni dengan memberikan pekerjaan rumah (PR) atau pemberian tugas. Pemberian pekerjaan rumah atau pemberian tugas bertujuan agar siswa aktif belajar di rumah dengan mengerjakan tugas yang telah diberikan di sekolah. Siswa sebagai pelajar, tugas utamanya adalah belajar. Belajar itu mencakup berbagai kegiatan antara lain: mengerjakan pekerjaan rumah, mempersiapkan diri dalam menghadapi test atau ulangan, mengadakan diskusi untuk memecahkan masalah, membuat ringkasan, melengkapi catatan, membaca buku-buku dan menentukan waktu belajar.

Melihat hal di atas, bagi guru yang menyadari hal ini, guru akan memberikan tugas kepada siswanya seperti memberikan pekerjaan rumah (PR), diskusi kelompok, membuat laporan, kegiatan ekstrakurikuler, dan lain sebagainya.

Pemberian pekerjaan rumah dimaksudkan agar siswa di rumah mengulangi pelajaran yang diajarkan di sekolah. Sebagaimana yang dikatakan Sumadi Suryabrata, "Belajar itu pada hakekatnya ialah mengulang-ulang bahan yang harus dipelajari dengan mengulang itu maka bahan pelajaran akan diingat dan dikuasai".

Berdasarkan pendapat di atas, dengan mengulang-ulang maka kesan yang akan ditimbulkan dalam pikiran akan lebih baik. Dengan demikian, pada gilirannya akan dapat meningkatkan hasil belajar siswa. Makin sering suatu pelajaran diulang maka akan semakin dikuasai pula bahan tersebut dan sewaktu waktu dapat dengan mudah digunakan dan diterapkan. Hal ini pun sesuai dengan pendapat dari HK. Jhos yang mengatakan bahwa"belajar sebanyak lima kali jauh lebih baik dari pada satu kali dalam lima hari pada satu pokok bahasan".

Dengan demikian pemberian pekerjaan rumah besar sekali pengaruhnya terhadap kegiatan belajar di rumah. Pemberian pekerjaan rumah adalah dimana murid diberikan tugas khusus di luar jam pelajaran. Dalam pelaksanaan metode ini siswa dapat mengerjakan tugasnya tidak hanya di rumah saja, tapi dapat dikerjakan juga di perpustakaan, di laboratorium, di ruang praktikum dan lain sebagainya untuk mendapat dipertanggung jawabkan kepada guru.

Untuk memperoleh prestasi belajar yang tinggi, maka perlu aktivitas belajar yang tinggi pula. Sebagaimana disebutkan oleh Nana Sudjana bahwa: "Salah satu ciri belajar yang berhasil dapat dilihat dari kadar kegiatan siswa belajar. Makin tinggi kegiatan siswa, makin tinggi peluang berhasilnya pengajaran”.

Berdasarkan pendapat di atas jelas bahwa untuk meningkatkan keberhasilan pembelajaran, siswa harus meningkatkan kegiatan belajarnya salah satu dari kegitan belajar tesebut adalah melaksanakan tugas yang telah diberikan oleh guru baik untuk melaksanakan di rumah maupun di sekolah. Terkadang siswa tidak melaksanakan pezsakerjaan rumah dikarenakan siswa sibuk bermain dengan teman-temannya sehingga siswa tersebut lupa waktu, dan juga karena kurangnya perhatian dari orang tua. Akibatnya anak akan kesulitan memahami pelajaran yang diberikan oleh gurunya di sekolah karena tidak mengerjakan tugas yang diberikan baik untuk di sekolah maupun di rumah. Dengan tidak 
dilaksanakannya tugas, oleh siswa tersebut maka akan mempengaruhi hasil belajar termasuk pada mata pelajaran Pendidikan Pancasila dan Kewarganegaraan (PKn). Sehingga pembelajaran kurang efektif yang akan mengakibatkan buruknya nilai siswa pada mata pelajaran Pendidikan Pancasila dan Kewarganegaraan (PKn).

\section{Pendidikan Pancasila dan} Kewarganegaraan adalah mata pelajaran yang bertujuan untuk mendidik generasi muda agar dapat mengenal apa-apa yang di wajibkan dalam berbangsa dan bernegara. Pada dasarnya mata pelajaran pendidikan pancasila dan kewarganegaraan adalah mata pelajaran yang menarik. Karena didalamnya terdapat pengetahuan-pengetahuan tentang hak dan kewajiban kita, supaya bisa menjadi rakyat yang makmur dan sejahtera. Tetapi yang terjadi pada umumnya siswa mengalami kesulitan dan bosan dalam mempelajari tentang kewarganegaraan, sejarah identitas bangsa Indonesia, hukum, pasal-pasal. Dalam pendidikan pancasila dan kewarganegaraan terdapat kebosanan siswa yang seharusnya bisa ditangani.

Pendidikan Pancasila dan Kewarganegaraan ini masih ketinggalan karena masih bersifat hafalan dan kurang mengembangkan proses berpikir, keterampilan proses dan sikap yang bisa dilatihkan melalui pembelajaran Pendidikan Pancasila dan Kewarganegaraan juga kurang dikembangkan.

Selain itu juga menyebabkan siswa jenuh dan mengantuk dalam menerima pelajaran Pendidikan Pancasila dan Kewarganegaraan, dan siswa juga sering keluar ruangan dengan alasan buang air kecil. Akibat siswa bergantian keluar, mengakibatkan terganggunya proses belajar mengajar.

Selain itu yang selama ini menjadi hambatan dalam pembelajaran Pendidikan Pancasila dan Kewarganegaraan adalah disebabkan kurang dikemasnya pembelajaran Pendidikan Pancasila dan Kewarganegaraan dengan metode yang menarik, sehingga pembelajaran Pendidikan Kewarganegaraan cenderung membosankan dan kurang menarik minat para siswa yang pada gilirannya hasil belajar, aktivitas, dan disiplin siswa kurang memuaskan. Disisi lain juga ada kecenderungan bahwa aktivitas siswa masih rendah hal ini disebabkan bahwa pembelajaran Pendidikan Kewarganegaraan dianggap sebagai suatu kegiatan yang membosankan, kurang menantang, akibatnya dalam pembelajaran Pendidikan Pancasila dan Kewarganegaraan rendahnya minat belajar siswa dalam pembelajaran. Kurang dikuasainya materimateri Pendidikan Kewarganegaraan oleh siswa, dan kurangnya variasi dalam pembelajaran.

Berdasarkan uraian di atas, peneliti terdorong untuk mengadakan penelitian dengan judul "Hubungan Tugas Pekerjaan Rumah (PR) Terhadap Hasil Belajar Siswa Pendidikan Kewarganegaraan Di Kelas VIII SMP Swasta Abdi Dharma T.P. 2018-2019".

\section{METODOLOGI PENELITIAN}

Penelitian ini dilaksanakan di SMP Swasta Abdi Dharma yang terletak di Jalan Siswa No. 264 Desa Paya Rengas, Kecamatan Hinai. Alasan peneliti memilih sekolah ini adalah karena letaknya strategis sehingga mempermudah dalam melaksanakan penelitian.

Adapun waktu penelitian ini dilaksanakan pada semester Ganjil tahun pembelajaran 2018/2019. 


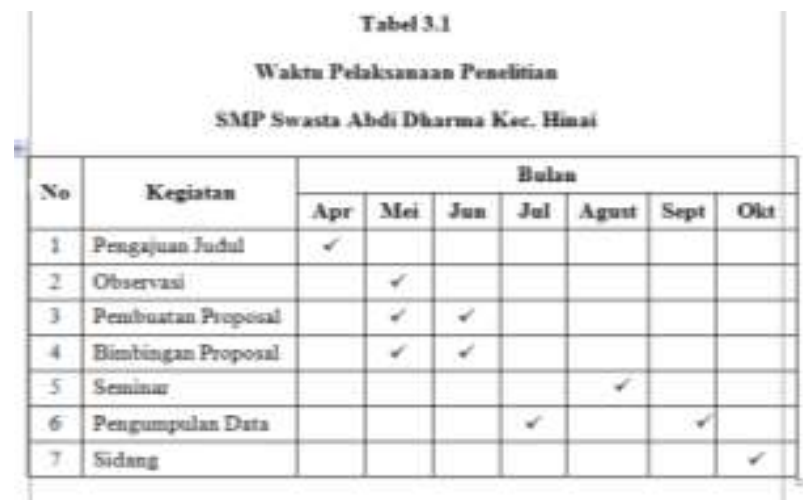

Kegiatan penelitian ini dilaksanakan untuk memahami sesuatu yang diteliti, maksudnya bahwa penelitian ini harus dapat menjelaskan sekumpulan objek yang lengkap secara keseluruhan.

\section{a. Populasi Penelitian}

Menurut Arikunto populasi adalah "keseluruhan subyek penelitian". Populasi pada penelitian ini adalah seluruh siswa-siswi kelas VIII di SMP Swasta Abdi Dharma Kecamatan Hinai tahun ajaran 2018/2019 yang berjumlah 30 siswa.

Tabel. Jumlah Populasi Siswa Kelas VIII SMP Swasta Abdi Dharma Kec. Hinai

\begin{tabular}{lll}
\hline No. & Kelas & $\begin{array}{l}\text { Jumlah } \\
\text { Siswa }\end{array}$ \\
\hline 1. & VIII & 30 \\
\hline & Jumlah & 30 \\
\hline
\end{tabular}

\section{b. Sampel Penelitian}

Menurut Sugiyono adalah suatu cara yang di tempuh dengan mengambil sampel yang bener-bener sesuai dengan keseluruhan dengan objek penelitian. Teknik pengambilan sampel dalam penelitian ini adalah total sampling, teknik pengambilan sampel dimana jumlah sampel sama dengan populasi. Alasan mengambil total sampling karna jumlah populasi yang kurang dari 100 seluruh populasi dijadikan sampel penelitian semuanya. Adapun sampel yang di ambil adalah keseluruhan siswa yang terdapat dalam satu kelas VIII yang jumlahnya 30 siswa.
Tabel. Sampel Penelitian Siswa Kelas VIIISMP Swasta Abdi Dharma Kec. Hinai

\begin{tabular}{lcc}
\hline No. & Kelas & $\begin{array}{c}\text { Jumlah } \\
\text { Siswa }\end{array}$ \\
\hline 1. & VIII & 30 \\
\hline & Jumlah & 30 \\
\hline
\end{tabular}

Menurut Sugiyono secara teoritis variabel penelitian dapat di definisikan sebagai "atribut seseorang, atau obyek, yang mempunyai "variasi" antara 1 orang dengan yang lain atau suatu obyek yang lain". Penelitian ini terdapat dua variabel yaitu variabel bebas (independent variabel) dan variabel terikat (dependent variabel).

Adapun variabel dalam penelitian ini adalah sebagai berikut:

Variabel:

a. Variabel bebas (X) adalah Hubungan tugas pekerjaan rumah (PR)

b. Variabel terikat (Y) adalah Hasil belajar siswa PKn

Jenis penelitian ini adalah quasi eksperiment (eksperimen semu) yaitu penelitian yang di maksudkan untuk mengetahui ada tidaknya pengaruh dari sesuatu yang dikenalkan pada subyek yaitu siswa. Penelitian ini dimaksudkan untuk mengetahui ada atau tidaknya Hubungan Tugas Pekerjaan Rumah (PR) Terhadap Hasil Belajar Siswa Pendidikan Kewarganegaraan di kelas VIII SMP Swasta Abdi Dharma Kecamatan Hinai.

\section{Angket}

Adapun alat pengumpulan data yang digunakan adalah :"Angket yaitu pengumpulan data dengan mengajukan kepada beberapa pertanyaan tertulis kepada siswa. Teknik angket digunakan untuk mendapatkan data yang berhubungan dengan pengaruh melaksanakan pekerjaan rumah. Jenis angket yang digunakan adalah jenis angket tertutup". Angket yang di uji cobakan berjumlah 20 butir pertanyaan dengan 5 option jawaban, yaitu : 
a. Option A untuk jawaban sangat setuju, dengan nilai 5.

b. Option B untuk jawaban setuju, dengan nilai 4.

c. Option $\mathrm{C}$ untuk jawaban ragu-ragu, dengan nilai 3.

d. Option D untuk jawaban tidak setuju, dengan nilai 2.

e. Option E untuk jawaban sangat tidak setuju, dengan nilai 1 .

Tabel. Kisi-Kisi Angket Tugas Pekerjaan Rumah (PR)

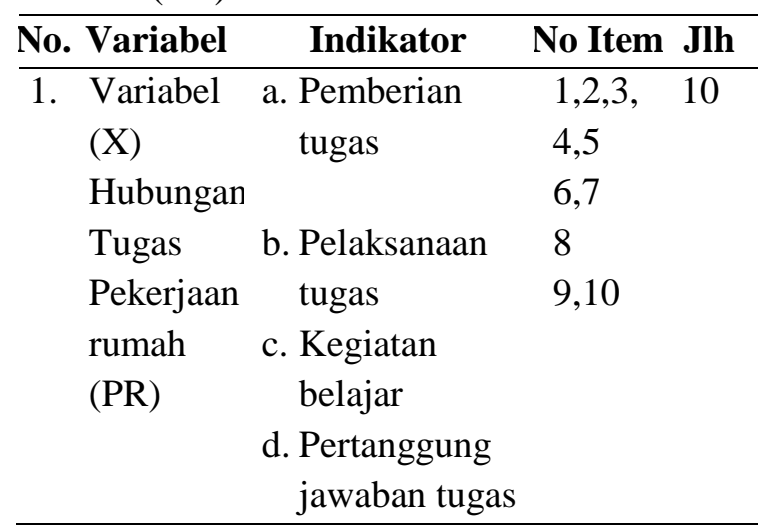

Tabel. Kisi-kisi Angket Hasil Belajar PKn Siswa

\begin{tabular}{lllll}
\hline $\begin{array}{c}\text { N } \\
\text { o. }\end{array}$ & $\begin{array}{c}\text { Variab } \\
\text { el }\end{array}$ & Indikator & $\begin{array}{c}\text { No } \\
\text { Item }\end{array}$ & Jlh \\
\hline 1. & Variab & a. Pengetahu & $1,2,3,4$ & 10 \\
& el (Y) & an &, 5 & \\
& Hasil & b. Pemahama & 6,7 & \\
& Belajar & n & 8 & \\
& Siswa & c. Penerapan & 9,10 & \\
& PKn & d. Penilaian & & \\
\hline
\end{tabular}

\section{Uji Instrumen Penelitian}

\section{Uji Validitas Angket}

Menurut Arikunto "Validitas adalah suatu ukuran yang menunjukkan tingkat atau kehasiatan instrumen". Untuk menguji alat ukur yang digunakan adalah Korelasi Product Moment, yaitu :

$$
r_{x y}=\frac{n \sum x y-\left(\sum x\right)\left(\sum y\right)}{\left.\sqrt{\left\{n \sum x^{2}\right.}-\left(\sum x\right)^{2}\right\}\left\{n \sum y^{2}-\left(\sum y\right)^{2}\right\}}
$$

Keterangan :

rxy : Korelasi product moment

$\sum \mathrm{X} \quad$ : Jumlah skor butir $\mathrm{X}$

$\left(\sum \chi\right)^{2}$ : Jumlah kuadrat skor butir $\mathrm{X}$

$\sum \mathrm{Y}$ : Jumlah pengamatan variabel $\mathrm{Y}$

$\left(\sum \mathrm{Y}^{2}\right)$ : Jumlah kuadrat skor butir y

$\sum X Y$ : Jumlah hasil perkalian variabel $\mathrm{X}$ dan $\mathrm{Y}$

$\mathrm{n} \quad$ : Jumlah pasangan pengamatan $\mathrm{Y}$ dan $\mathrm{X}$

Untuk menafsirkan harga validitas tes, maka harga tersebut dikonfirmasikan kritik rtabel Product Moment dengan $\alpha=0,05$. Jika rhitung $\geq$ rtabel, maka butir instrument tes tersebut dikatakan valid.

\section{Uji Reabilitas Angket}

Uji dilakukan agar angket tersebut mempunyai taraf kepercayaan yang tinggi sehingga dapat memberikan hasil yang tepat. Untuk menguji reabilitas angket digunakan rumus seperti :

$$
r_{11}=\left(\frac{n}{n-1}\right)\left(1-\frac{\sum a b^{2}}{a t^{2}}\right)
$$

Keterangan:

$\mathrm{r}_{11}=$ Reliabilitas tes secara keseluruhan

$\mathrm{n} \quad=$ Banyaknya item atau soal

$\alpha \quad=$ Varian Total

$\sum \alpha \mathrm{b}=$ Jumlah Varian Butir

Kreteria derajat reabilitas suatu angket tersebut sebagai berikut :

$0,80 \leq \sigma>1$ : derajat reabilitas suatu angket sangat tinggi

$0,61 \leq \sigma>0,80$ : derajat reabilitas sustu angket tinggi

$0,41 \leq \sigma>0,60$ : derajat reabilitas suatu angket sedang

$0,20 \leq \sigma>0,410$ : derajat reabilitas suatu angket sangat rendah

Teknis analisis data yang digunakan untuk mengetahui adanya pengaruh tugas pekerjaan rumah (pr) terhadap hasil belajar siswa adalah dengan menggunakan rumus korelasi Produk Moment yaitu: 
$r_{x y}=\frac{n \sum x y-\left(\sum x\right)\left(\sum y\right)}{\left.\sqrt{\left\{n \sum x^{2}\right.}-\left(\sum x\right)^{2}\right\}\left\{n \sum y^{2}-\left(\sum y\right)^{2}\right\}}$

$r_{\chi \gamma}=$ korelasi produk moment

$\sum \mathrm{x}=$ jumlah skor butir $\mathrm{x}$

$\sum \mathrm{x}^{2}=$ jumlah kuadrat skor butir $\mathrm{x}$

$\sum \mathrm{y}=$ jumlah skor butir $\mathrm{y}$

$\sum \mathrm{y}^{2}=$ jumlah kuadrat skor butir $\mathrm{y}$

$\sum x y=$ perkalian option dan skor total

$\mathrm{N}=$ jumlah sampel yaitu:

Pengujian hipotesis digunakan uji " $\mathrm{t}$ ",

$$
\mathrm{t}=\frac{\sqrt[r]{N-2}}{\sqrt{1-r^{2}}}
$$

Dimana: $\quad \mathrm{t}=$ nilai uji $\mathrm{t}$

$\mathrm{r}=$ nilai $\mathrm{r}$ korelasi

$\mathrm{n}=$ jumlah sampel

\section{HASIL PENELITIAN DAN PEMBAHASAN}

\section{Deskripsi Hasil Penelitian}

Penelitian ini merupakan penelitian quasi eksperimen yang bertujuan untuk mengetahui ada tidaknya hubungan tugas pekerjaan rumah (pr) terhadap hasil belajar siswa pendidikan kewarganegaraan di kelas VIII SMP Swasta Abdi Dharma Kec. Hinai tahun pelajaran 2018/2019. Objek penelitian ini adalah seluruh siswa kelas VIII yang berjumlah 30 siswa. Sebelum melakukan penyebaran angket terlebih dahulu peneliti mengobservasi sekolah. Penyebaran angket dengan alternatif yang ada dimaksud untuk memudahkan siswa dalam memberi pilihan jawaban sesuai dengan kemampuan mereka.

Setelah diadakan penelitian dan pengumpulan data di lapangan maka diperoleh berbagai data tentang responden dalam kaitannya dengan Hubungan Tugas Pekerjaan Rumah (pr) Terhadap Hasil Belajar Siswa PKn di kelas VIII SMP Swasta Abdi Dharna. Data yang diperoleh selama penelitian di lapangan disajikan dalam bentuk analisis data dengan sampel responden seluruh siswa yang ada pada kelas VIII SMP wasta Abdi Dharma yaitu sebanyak 30 orang siswa.
Dalam hal ini disajikan 10 pertanyaan dengan daftar pertanyaan dari no. 1 sampai dengan 10 untuk masing-masing variabel X (10 angket) yang disebarkan kepada responden yang setara dengan responden untuk mencari kevaliditasan angket. Setelah data terkumpul dan mendapatkan kevaliditasannya, baru data yang valid saja yang di sebarkan kepada responden. Dengan demikian data yang dianalisis pada BAB ini adalah data yang diperoleh dari 30 responden.

\section{A. Uji Instrumen Penelitian}

\section{Uji Validitas}

Uji validitas ini dilaksanakan untuk mengetahui tingkat kesahihan instrument dalam mengumpulkan data. Uji ini dilakukan dengan mengkorelasi setiap item pertanyaan skor total dan dengan menggunakan rumus korelasi product moment. Untuk uji validitas angket penelitian ini di sebarkan pada siswa yang merupakan sampel. Variabel (X) angket hubungan tugas pekerjaan rumah (pr) 10 item pertanyaan atau pernyataan dari angket yang disebarkan diketahui 8 item valid dan beberapa item pertanyaan tidak valid.

\section{Uji Reabilitas}

Uji reabilitas digunakan untuk mengetahui sejauh mana angket tersebut dapat dipercaya untuk digunakan sebagai alat pengumpul data. Instrumen yang baik tidak akan berubah-ubah meskipun dilakukan pengujian berulang-ulang atau dapat di andalkan dan tetap konsisten jika dilakukan 2 kali pengukuran atau lebih pada kelompok yang sama dengan alat ukur yang sama.

Bagian ini merupakan pembahasan yang bersumber dari data-data yang diperoleh melalui angket penelitian yaitu untuk variabel $\mathrm{X}$ (hubungan tugas pekerjaan rumah) dan variabel Y (hasil belajar siswa PKn). 
Tabel 4.1

Rekapitubsi Jawaban Angket Hubugan Tugas

Pekrerjaan Rumah (pr) Sisrra Pada Mata Pelajaran

Pendidikan Kew arganegaraan VariabelX

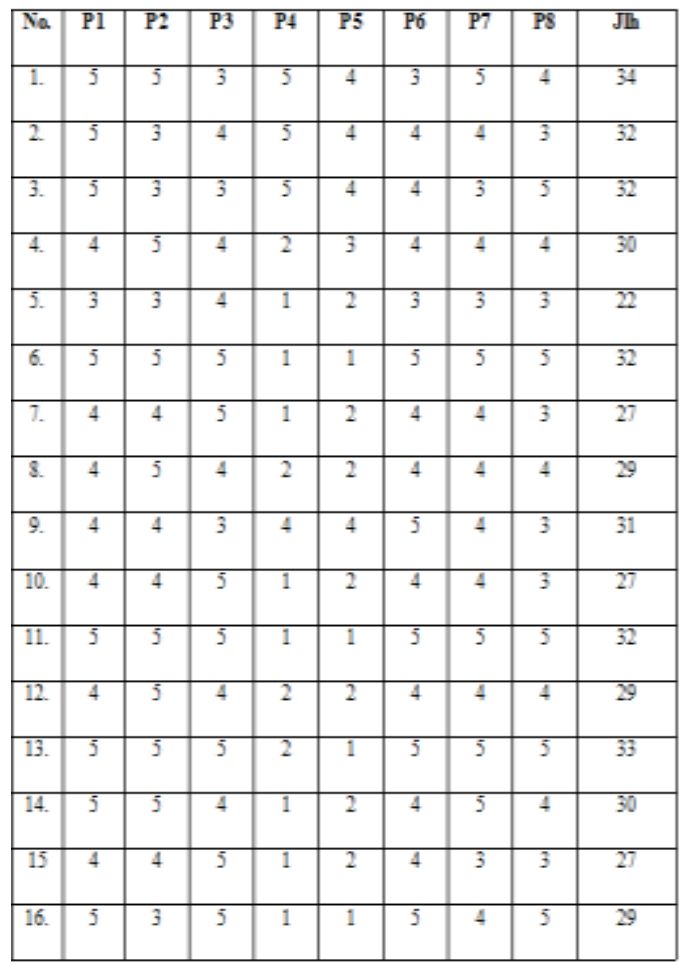

Berdasarkan hasil Tabel 4.1 yaitu variabel X Hubungan Tugas Pekerjaan Rumah (PR) dengan jumlah angket 8 pertanyaan dan dengan jumlah keseluruhan skor 916 untuk keseluruhan item pertanyaan.
Tabel 4.2

Hasil Belajar Sisw a PKn

Variabel Y

\begin{tabular}{|c|c|}
\hline No. & Nilai PKn \\
\hline $\mathbf{l}$. & 70 \\
\hline $\mathbf{2 .}$ & 75 \\
\hline $\mathbf{3 .}$ & 68 \\
\hline $\mathbf{4 .}$ & 70 \\
\hline $\mathbf{5 .}$ & 75 \\
\hline $\mathbf{6 .}$ & 75 \\
\hline $\mathbf{7 .}$ & 67 \\
\hline $\mathbf{8 .}$ & 69 \\
\hline $\mathbf{9 .}$ & 70 \\
\hline $\mathbf{1 0 .}$ & 75 \\
\hline $\mathbf{1 1 .}$ & 75 \\
\hline $\mathbf{1 2 .}$ & 69 \\
\hline $\mathbf{1 3 .}$ & 69 \\
\hline $\mathbf{1 4 .}$ & 70 \\
\hline $\mathbf{1 5 .}$ & 68 \\
\hline $\mathbf{1 6 .}$ & 70 \\
\hline $\mathbf{1 7 .}$ & 70 \\
\hline & \\
\hline & \\
\hline
\end{tabular}

Berdasarkan hasil Tabel 4.2 yaitu variabel Y Hasil Belajar Siswa PKn. Data hasil belajar siswa ini diambil dari nilai soal yang di berikan oleh peneliti kepada siswa dalam mata pelajaran Pendidikan Kewarganegaraan pada kelas VIII SMP Swasta Abdi Dharma Kec. Hinai.

Selanjutnya dimasukkan kedalam Tabel 4.3 yaitu hasil perhitungan korelasi antara variabel X dan variabel Y sebagai berikut : 
Tabel $\mathbf{4 . 3}$

Hasil Perhitungan Kor elasi Antara VariabelX (Hubungan Tugas Pekerjaan Rumah)

Dan Variabel Y (Hasil Belajar Siswa PKn)

\begin{tabular}{|c|c|c|c|c|c|}
\hline No. & $\mathbf{X}$ & $\mathbf{Y}$ & $\mathrm{X} 2$ & Y2 & $\mathrm{XY}$ \\
\hline 1. & 34 & 70 & 1156 & 4900 & 2380 \\
\hline 2. & 32 & 75 & 1024 & 5625 & 2400 \\
\hline 3. & 32 & 72 & 1024 & 5184 & 1836 \\
\hline 4. & 30 & 70 & 900 & 4900 & 2100 \\
\hline 5. & 22 & 75 & 484 & 5625 & 1650 \\
\hline 6. & 32 & 75 & 1024 & 5625 & 2400 \\
\hline 7. & 27 & 73 & 729 & 5329 & 2336 \\
\hline 8. & 29 & 70 & 841 & 4900 & 2170 \\
\hline 9. & 31 & 70 & 961 & 4900 & 2170 \\
\hline 10. & 27 & 75 & 729 & 5625 & 2025 \\
\hline 11. & 32 & 75 & 1024 & 5625 & 2400 \\
\hline 12. & 29 & 74 & 841 & 5476 & 1998 \\
\hline 13. & 33 & 74 & 1089 & 5476 & 1998 \\
\hline 14. & 30 & 70 & 900 & 4900 & 2100 \\
\hline 15. & 27 & 72 & 729 & 5184 & 1836 \\
\hline
\end{tabular}

Berdasarkan tabel $\mathrm{X}$ dan $\mathrm{Y}$ diatas diperoleh hasil perhitungan sebagai berikut :

$\mathrm{N}=30$

$\sum \mathrm{X}=916$

$\sum \mathrm{Y}=2174$

$\sum \mathrm{X} 2=28172$

$\sum \mathrm{Y} 2=157672$

$\sum X Y=67749$

Selanjutnya hasil dari perhitungan diatas tersebut dimasukkan kedalam rumus korelasi product moment yaitu:

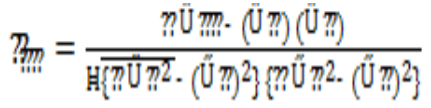

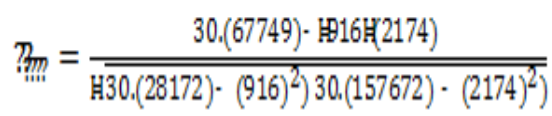

$$
\begin{aligned}
& T_{? m}=\frac{2032470-1991384}{\mathrm{H}(845160-839056)(4730160-4726276)} \\
& ?_{? m}=\frac{41086}{\mathrm{H}(6104)(3884)} \\
& T_{? m}=\frac{41086}{4 \overline{23707936}} \\
& ?_{m ! n}=\frac{41086}{4869,079}=0,843
\end{aligned}
$$

Dari hasil perhitungan di atas dengan menggunakan rumus korelasi product moment diperoleh nilai $\mathbf{r}_{\mathrm{x} \gamma}=0,843$ maka dari itu dapat disimpulkan bahwa terdapat pengaruh positif sebesar 0,843 antara hubungan tugas pekerjaan rumah (pr) terhadap hasil belajar siswa pendidikan kewarganegaraan kelas VIII.

Selanjutnya untuk dapat memberikan interprestasi terdapat kuat dan rendahnya hubungan itu, maka digunakan pedoman interpensi koefisien seperti pada tabel dibawah ini :

Tabel 4.4

Pedoman Untuk Memberikan Interpr etasi Koefisien Korelasi

\begin{tabular}{|c|c|}
\hline Interval Koefisien & Tingkat Hubungan \\
\hline $0,00-0,199$ & Sangat Rendah \\
\hline $0,20-0,399$ & Rendah \\
\hline $0,40-0,599$ & Sedang \\
\hline $0,60-0,799$ & Kuat \\
\hline $0,80-1,000$ & Sangat Kuat \\
& \\
\hline
\end{tabular}

Berdasarkan tabel diatas, maka koefisien korelasi yang ditemukan sebesar 0,843 dan termasuk pada kategori sangat kuat. Jadi Hubungan yang kuat antara Tugas Pekerjaan Rumah (PR) terhadap Hasil Belajar Siswa Pendidikan Kewarganegaraan Kelas VIII.

Harga $r$ hitung tersebut selanjutnya dibandingkan dengan harga $r$ tabel bentuk taraf signifikasi $5 \%$ dan $\mathrm{dk}=\mathrm{N}-2=30-2=28$, maka rtabel $=0,374$ dan $r_{\text {hitung }}=0,843$ hal ini dapat disimpulkan bahwa $r_{\text {hitung }}(0,843)>r_{\text {tabel }}(0,374)$ berarti ada hubungan antara variabel $\mathrm{X}$ dan $\mathrm{Y}$.

Untuk mengetahui signifikan hubungan tugas pekerjaan rumah (pr) terhadap hasil 
belajar siswa pendidikan kewarganegaraan kelas VIII digunakan perhitungan uji t, untuk menguji hipotesis apakah diterima atau ditolak, maka selanjutnya hasil dari $r$ hitung diuji dengan menggunakan rumus uji $t$ sebagai berikut :

$t=\frac{\sqrt[r]{N-2}}{\sqrt{1-r^{2}}}$

$t=\frac{0,843 \sqrt{30-2}}{\sqrt{1-(0,843)^{2}}}$

$t=\frac{(0,843)(5,2915)}{\sqrt{1-0,7106}}$

$t=\frac{4,4607345}{\sqrt{0,2894}}$

$t=\frac{4,4607345}{0,5379}=8,292$

Berdasarkan perhitungan diperoleh harga $t_{\text {hitung }}=8,292$ tabel dengan taraf kepercayaan $\mathrm{a}=0,05$ dan $\mathrm{N}=30-2=28$ yaitu 1,70113 selanjutnya $\mathrm{Ha}$ diterima jika $t_{\text {hitung }}>t_{\text {tabel }}$. Berdasarkan daftar $t_{\text {tabel }}=1,70113$ dapat dilihat bahwa $t_{\text {hitung }}>t_{\text {tabel }}$ yaitu 8,292>1,70113 maka dapat disimpulkan bahwa Ha diterima dan Ho ditolak.

Artinya ada hubungan yang signifikan antara tugas pekerjaan rumah (pr) terhadap hasil belajar siswa pendidikan kewarganegaraan kelas VIII SMP Swasta Abdi Dharma Kec. Hinai T.P 2018/2019.

Dari analisis data telah terbukti bahwa terdapat Hubungan yang signifikasi pada kategori "sangat kuat" antara Tugas Pekerjaan Rumah (PR) terhadap Hasil Belajar Siswa Pendidikan Kewarganegaraan. Hal ini ditunjukkan dengan nilai korelasi yang diperoleh dari perhitungan korelasi Product Moment ( $\left.r_{\text {hitung }}=0,843>r_{\text {tabel }}=0,374\right)$ dan ( $\left.\mathrm{t}_{\text {hitung }}=8,292>\mathrm{t}_{\text {tabel }}=1,70113\right)$.

Penelitian ini telah dilakukan secermat mungkin yaitu dengan mengupayakan kondisikondisi yang menggantung dalam proses penelitian. Namun, penelitian ini tidak terlepas dari berbagai kekurangan dan kelemahan. Adapun kendala-kendala yang dihadapi dalam penelitian sejak dari pembuatan rangkaian pelaksanaan sehingga pengolahan data adalah sebagai berikut :
1. Sulit untuk mengukur secara tepat tentang Hubungan Tugas Pekerjaan Rumah (PR) terhadap Hasil Belajar siswa karena tes yang digunakan hanya angket yang berjumlah 20 .

2. Bila dilihat dari hasil jawaban angket, kemungkinan jawaban angket tidak di isi dengan sungguh-sungguh dan tidak sebenar-benarnya.

3. Kurang memahami ruang lingkup statistik secara detail sehingga agak menyulitkan peneliti dan membutuhkan waktu cukup lama dalam pengolahan data.

4. Keterbatasan waktu yang dimiliki oleh penulis dalam melakukan riset lebih lanjut pada siswa SMP Swasta Abdi Dharma.

Disamping adanya keterbatasan dana, buku panduan, waktu serta moril dan material yang peneliti miliki, maka penelitian ini masih banyak kekurangan dan kelemahan. Oleh sebab itu, maka dengan senang hati mengharapkan adanya kritikan yang membangun untuk menyempurnakan penelitian ini.

\section{KESIMPULAN DAN SARAN}

Dari pengolahan data yang dilakukan tentang Hubungan Tugas Pekerjaan Rumah (PR) terhadap Hasil Belajar Siswa Pendidikan Kewarganegaraan Kelas VIII SMP Swasta Abdi Dharma maka dapat diperoleh kesimpulan sebagai berikut:

1. Dari penelitian yang telah dilakukan ditemukan bahwa hubungan tugas pekerjaan rumah (pr) berpengaruh terhadap hasil belajar siswa pendidikan kewarganegaraan kelas VIII smp Swasta Abdi Dharma, ini terbukti dengan nilai korelasi $r_{\text {hitung }}=0,843$ Dari tabel $r$ Product Moment untuk N =30$2=28$ diperoleh rtabel $=0,374$ Hal ini menunjukkan bahwa $r_{\text {hitung }}=0,843>$ $\mathrm{r}_{\text {tabel }}=0,374$ maka koefisien korelasi sangat kuat.

2. Dari perhitungan hipotesis diketahui dan diperoleh $t_{\text {hitung }}=8,292$ dan signifikan $\mathrm{a}=0,05=5 \%$ dan $\mathrm{t}=\mathrm{N}-2=$ $30-2=28$ diperoleh $\mathrm{t}_{\text {tabel }}=1,70113$ maka berdasarkan hasil yang diperoleh 
$t_{\text {hitung }}=8,292>t_{\text {tabel }}=1,70113$ kita dapat menyimpulkan bahwa ada hubungan yang signifikan antara tugas pekerjaan rumah (pr) dengan hasil belajar siswa pendidikan kewarganegaraaan, dan hipotesis diterima.

Dengan demikian dapat disimpulkan bahwa tugas pekerjaan rumah (pr) ada hubungannya terhadap hasil belajar siswa pendidikan kewarganegaraan kelas VIII SMP Swasta Abdi Dharma T.P. 2018/2019.

Setelah diperoleh kesimpulankesimpulan diatas, maka penulis mengajukan saran antara lain:

1. Tugas Pekerjaan Rumah (PR) yang diberikan oleh guru sangat berperan penting dalam mengasah kemampuan dan meningkatkan hasil belajar siswa. Siswa diharapkan mampu belajar dan bertanggung jawab dengan baik.

2. Bagi pihak sekolah/guru disarankan adanya pembinaan terhadap aktivitas siswa kearah yang positif seperti melaksanakan kegiatan belajar, program ekstrakurikuler dan memberikan masukan kepada mereka akan pentingnya belajar yang baik sesuai dengan peraturan sekolah.

3. Bagi peneliti, dengan adanya penelitian ini dapat memperluas wawasan pengetahuan dan bahan tambahan (bekal) dikemudian hari.

\section{DAFTAR PUSTAKA}

Arikunto Suharsimi, Prosedur Penelitian Suatu Pendekatan Praktik, Rineka Cipta, 2010.

Arikunto Suharsimi, Prosedur Penelitian, Rineka Cipta, 2010.

Daradjat Zakia, Metodik Khusus Pengajaran Agama Islam, Jakarta, Bumi Aksara, 2004.

Dkk. Zuhairini, Metodik khusus Pendidikan Agama, Surabaya, Usaha Nasional, 2005.
Jhos HK, Cara Belajar Efektif di Perguruan Tinggi, Bandung, Rajawali, 2007.

Kartono Kartono, Bimbingan Belajar di SMA dan Perguruan Tinggi, Rajawali, Jakarta,1996.

Mulyasa, E, Menjadi Guru Profesional Menciptakan Pembelajaran Kreatif dan Menyenangkan, Bandung, Remaja Rosda Karya, 2008.

N.K, Roestiyah, Strategi Belajar Mengajar, Jakarta, Rineka Cipta, 2008.

N.K, Roestiyah, Masalah-masalah Ilmu Keguruan, Jakarta, Bina Aksara, 2003.

Ramayulis, Metodologi Pendidikan Agama Islam, Jakarta, Kalam Mulia, 2005.

S. Nasution, Didaktik Asas-asas mengajar, Jakarta, Bumi Aksara, 2010.

Slameto, Belajar dan Faktor-faktor yang Mempengaruhinya, Rineka Cipta, Jakarta, 2003.

Sudjana Nana, Dasar-Dasar Proses Belajar Mengajar, Jakarta, Sinar Baru, 2011.

Sudjana Nana, Metode Statistika, Bandung, Tarsito, 2005.

Sugiyono, Rumus Dan Data Dalam Aplikasi Statistik, Alfabeta, Bandung : 2007.

Sugiyono, Metode Penelitian Pendidikan Pendekatan Kuantitatif, Kualitatif, dan $R \& D$, Alfabeta, Bandung : 2013.

Surya Subrata Sumadi, Psikologi Pendidikan, Jakarta, Rineeka Cipta, 2010.

Syaiful Bahri Jamarah dan Azwan Zain, Strategi Belajar Mengajar, Jakarta, Rineka Cipta, 2006.

Winkel, W, S. 1983. Psikologi Pendidikan dan Evaluasi Belajar. Jakarta: Gramedia,1983 